\title{
Soil microbial biomass in organic farming system
}

\author{
Biomassa microbiana do solo em sistemas orgânicos
}

\section{Ademir Sérgio Ferreira de Araújo ${ }^{\mathrm{I}}$ Wanderley José de Melo ${ }^{\mathrm{II}}$}

\section{- REVIEW -}

\section{ABSTRACT}

Agricultural production systems have to combine management practices in order to sustain soil's profitability and quality. Organic farming is gaining worldwide acceptance and has been expanding at an annual rate of $20 \%$ in the last decade, accounting for over 24 million hectares worldwide. Organic practices avoid applications of synthetic fertilizers and pesticides, rely on organic inputs and recycling for nutrient supply, and emphasize cropping system design and biological processes for pest management, as defined by organic farming regulation in the world. In comparison with conventional farming, organic farming has potential benefits in improving food quality and safety. Plant production in organic farming mainly depends on nutrient release as a function of mineralization processes in soils. The build-up of a large and active soil microbial biomass is important pool of accessible nutrients, therefore, is an important priority in organic farming. In organic farming, there is positive effect of quantity and quality of inputs of organic residues on soil microbial biomass. In this way, the organic systems are extremely important for the increase of the soil fertility and the maintenance of the environmental sustainability.

Key words: soil microorganisms, microbial activity, organic $C$, soil quality.

\section{RESUMO}

A produção agrícola tem de combinar práticas para prover a sustentabilidade do solo. A agricultura orgânica está ganhando aceitação mundial e cresce à taxa anual de $20 \%$ na última década, contabilizando mais de 24 milhões de hectares. As práticas orgânicas evitam o uso de fertilizantes sintéticos e pesticidas, enfatiza a aplicação de matéria orgânica, como também a reciclagem de nutrientes e de processos biológicos para manejo de pragas, através das regras dos sistemas orgânicos no mundo. Em comparação com a agricultura convencional, os sistemas orgânicos têm potencial de melhorar a qualidade e a segurança dos alimentos. A produção das plantas no sistema orgânico depende da liberação de nutrientes pelo processo de mineralização microbiana no solo. A construção de uma grande e ativa biomassa microbiana é um importante reservatório de nutrientes disponiveis. Dessa forma, isso é uma prioridade no sistema orgânico. Em sistemas orgânicos, há efeitos positivos da quantidade e da qualidade das fontes de carbono orgânico sobre a biomassa microbiana do solo. Nesse sentido, as práticas do sistema orgânico são extremamente importantes para o aumento da fertilidade do solo e para a manutenção da sustentabilidade ambiental.

Palavras-chave: microrganismos do solo, atividade microbiana, C orgânico, qualidade do solo.

\section{INTRODUCTION}

In the context of social, economical and ecological sustainability, the agriculture is considered as an important area for human development. Nowadays, to respond to human demands, conventional farming plays an important role in improving food and fibre productivity, but has been is largely dependent on intensive inputs of synthetic fertilizers and pesticides. Theses inputs can, usually, cause soil degradation (REGANOLD et al., 1987),

'Departamento de Engenharia Agrícola e Solos, Centro de Ciências Agrárias, Universidade Federal do Piauí (UFPI), 64049-550, Teresina, PI, Brasil. E-mail: asfaruaj@yahoo.com.br. Autor para correspondência.

"Departamento de Tecnologia, Faculdade de Ciências Agronômicas e Veterinárias (FCAV), Universidade Estadual Paulista (UNESP), Jaboticabal, SP, Brasil. 
reduction of biodiversity (LUPWAYI et al., 2001) and consequently decrease environmental sustainability (HORRIGAN et al., 2002).

Organic farming systems avoid applications of synthetic fertilizers and pesticides, promote organic inputs and recycling of nutrients, and emphasize cropping system design and biological processes for pest management (RIGBY \& CACERES, 2001). These practices promote, mainly, the improvement of soil quality and the maintenance of the environmental quality. In this way, they may thus reduce some negative effects attributed to conventional farming (REGANOLD et al., 1987).

Soil is a dynamic, living, natural body that is vital to the function of terrestrial ecosystems and represents a unique balance between physical, chemical and biological factors. Soil quality is the capacity of a specific kind of soil to function, within natural or managed ecosystem boundaries, to sustain plant and animal growth, maintain or improve water and air quality, and support human health and habitation (DORAN \& PARKIN, 1994). Additionally, soil is a complex system, in which, plant, macro, meso and microorganisms dispute water and nutrient sources for survival and whose physical, chemical and biological properties shows high spacial temporal changes (MELO, 1994).

In this context, microbial biomass has been suggested as indicator of soil quality. The microbial biomass is the main living component of soil organic matter and promotes fundamental functions for the maintenance or improvement of soil quality, being primarily affected by the changes in the soil use and management. Thus, the agricultural practices in organic farming can influence the soil microbial biomass and promote changes in soil quality.

Organic farming system

Organic farming can be defined as an approach to agriculture where the aim is to create and integrated, human, environmentally and economically sustainable agricultural production systems. Organic agriculture is distinct from conventional agriculture through alternative agricultural practices, world view and values (WATSON et al., 2006). Maximum reliance is placed on locally or farm-derived renewable resources and the management of self-regulating ecological and biological processes and interactions in order to provide acceptable levels of crop, livestock and human nutrition, protection from pests and diseases, and an appropriate return to the human and other resources employed.

In the world, organic farming is regulated and legalized by the International Federation of Organic
Agriculture Movements (IFOAM). In the last decade, organic farming system is gaining worldwide acceptance and has been expanding at annual rate of $20 \%$, accounting for over 24 million hectares worldwide (LOTTER, 2003). Australia has the largest land area under organic management (about 10 million hectares), followed by Argentina (about 3 million hectares), Italy (about 1.2 million hectares), and the USA (about 1 million hectares) (WILLER \& YUSSEFI, 2004). European countries have the highest proportion of land under organic management. For instance, organic land accounts for about $12 \%$ of the total agricultural area in Austria, $10 \%$ in Switzerland, $8 \%$ in Italy, and $7 \%$ in Finland (WILLER \& YUSSEFI, 2004). It is estimated that by 2010 organically farmed land will occupy 10 $20 \%$ of total agricultural land areas in many European countries (GREENE \& KREMEN, 2003). In the US, the organic market grew around $20 \%$ annually between 2002 and 2007 (WILLER \& YUSSEFI, 2004). Brazil counts as one of the leading countries worldwide in organic farming $(\sim 850,000 \mathrm{ha})$ and occupies the $6^{\text {th }}$ position in the world (ARAÚJO et al., 2008).

The main characteristics of organic farming include: a) Protecting the long-term fertility of soils by maintaining high level of organic matter content and increasing soil biological activity; b) Providing crop nutrients indirectly using relatively insoluble nutrient sources which are slowly available to plant uptake by the action of soil micro-organisms; c) Nitrogen selfsufficiency through the use of legumes and biological nitrogen fixation, as well as effective recycling of organic materials including crop residues and livestock manures; d) Weed, disease and pest control relying primarily on crop rotations, natural predators, diversity, organic manure, resistant varieties and limited (preferably minimal) thermal, biological and chemical intervention; e) The extensive management of livestock, paying full regard to their evolutionary adaptations, behavioral needs and animal welfare issues with respect to nutrition, housing, health, breeding and rearing; f) Careful attention to the impact of the farming system on the wider environment and the conservation of wildlife and natural habitats.

On the other hand, the main characteristics of conventional agriculture are high inputs of chemical fertilizers and pesticides (agrochemicals). In the last decades, intensive use of agrochemicals has increased the toxicity in soils and also has degraded its status. Organic farming is becoming a major tool for sustaining the soil quality degraded by synthetic chemicals by increasing crop production and therefore, the use of bio-agents as biofertilizers or biopesticides which is an integral part of organic farming especially in vegetable cultivation (TRUU et al., 2008). 
Since only limited amounts of permitted fertilizers are used by organic farmers, plant production depends almost exclusively on nutrient transformations in soils. Because nutrient transformations are primarily controlled by microorganisms, an active soil microflora and a considerable pool of accessible nutrients are very important to the functioning of organic farming systems. In this way, the maintenance of adequate status of soil microbial biomass and organic matter is crucial for success in organic farming system.

Organic farming on soil microbial biomass

The microorganisms present important functions in the soil, as nutrient cycling and the degradation of pollutant (pesticides, urban and industrial wastes) (DICK, 1997; HANEY et al., 2002; WATANABE \& HAMAMURA, 2003; ARAÚJO et al., 2003; ARAÚJO \& MONTEIRO, 2006). Additionally, soil microorganisms promote other important functions for environmental sustainability (Figure 1). According to POWLSON et al. (1987), the main function of microorganisms is mediate soil processes and present high rates of turnover, being a sensitive indicator of changes in soil organic matter.

Soil's microorganism represents the fraction of the soil responsible for the energy and nutrient cycling and the regulation of organic matter transformation. The organic residues are, in this way, converted to biomass or mineralized to $\mathrm{CO}_{2}, \mathrm{H}_{2} \mathrm{O}$ and

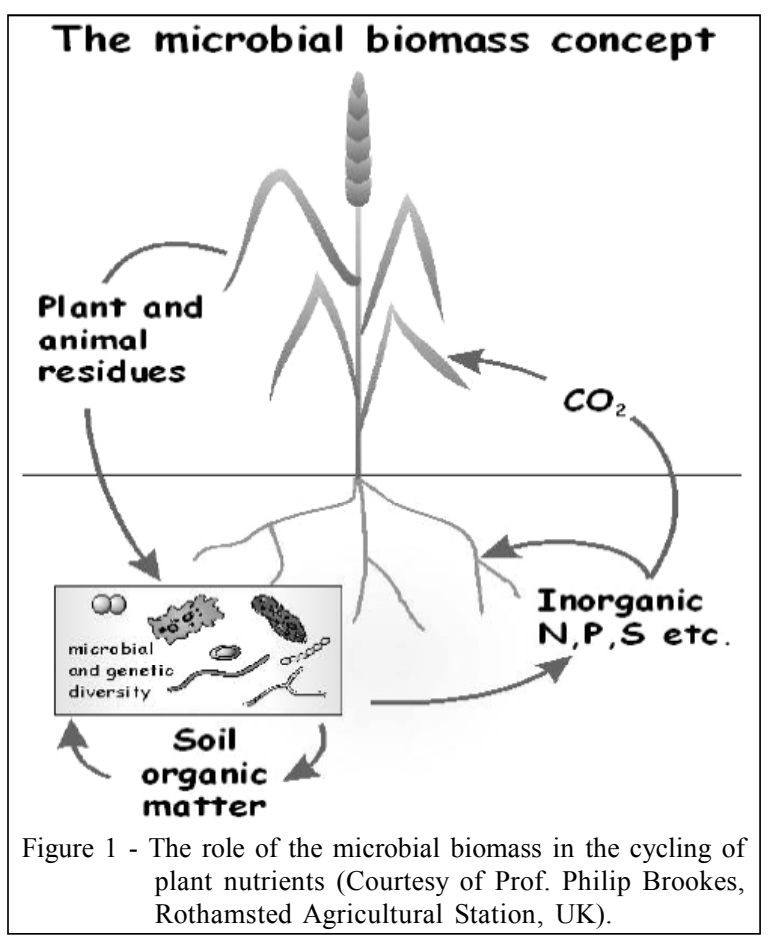

mineral nutrients representing an important pool of nutrients (N, $\mathrm{P}$ and $\mathrm{S}$ ), which are continually assimilated during the microorganism's growth. Thus, microbial biomass is considered an important source and sink of nutrients in the soil, promoting mineralization of organic matter in inorganic nutrients $\left(\mathrm{NH}_{4}^{+}, \mathrm{NO}_{3}^{-}, \mathrm{H}_{2} \mathrm{PO}_{4}^{-}, \mathrm{SO}_{4}^{2-}\right.$ and $\mathrm{CO}_{2}$ ) and consequent availability for plant growth, or immobilizing the nutrients in microbial tissues for its maintenance and growth. Consequently, soils that maintain a high content of microbial biomass are capable to accumulate and cycle nutrients in the soil system (GREGORICH et al., 1994).

The soil microbial biomass comprises all soil organisms with a volume of less than about $5 \times 10^{3} \mathrm{um}^{3}$, other than plant tissue, and can thus be considered as the living part of soil organic matter (BROOKES, 2001). The proportion present as living microbial cells (microbial biomass $\mathrm{C}$ in $\mathrm{mg}$ per $\mathrm{kg}$ of soil) typically comprises 1 to $5 \%(\mathrm{w} / \mathrm{w})$ of total organic $\mathrm{C}$, and microbial $\mathrm{N}$ forms 1 to $6 \%(\mathrm{w} / \mathrm{w})$ of total organic $\mathrm{N}$ (JENKINSON \& LADD, 1981; WARDLE, 1992). The total amounts of microbial $\mathrm{C}$ and $\mathrm{N}$ in soil consequently tend to reflect the total organic matter contents of soils.

In the last ten years, several studies were conducted, in the world, in order to evaluate the effect of organic practices on soil microbial biomass (GUANAPALLA\& SCOW, 1998; LUNDQUIST et al., 1999; KAPKIYAI et al., 1999; FLIESBACH \& MADER, 2000; GLOVER et al., 2000; BETTIOL et al., 2002; MADER et al., 2002; THEODORO et al., 2003; OEHL et al., 2004; PARFITT et al., 2005; GADJA\& MARTYNIUK, 2005; AYAGA et al., 2006; MELERO et al., 2006; TU et al., 2006; XAVIER et al., 2006; LIMA et al., 2007; ALCANTARA et al., 2007; VALARINI et al., 2007; BRIAR et al., 2007; ESPERSCHÜTZ et al., 2007; OLIVEIRA et al., 2007; MALUCHE-BARETTA et al., 2007; ARAÚJO et al., 2008; MONOKROUSOS et al., 2008; SAMPAIO et al., 2008; STARK, 2008; LAGOMARSINO et al., 2009; ARAÚJO et al., 2009). Generally, the results show positive influence of inputs of organic residues, with high $\mathrm{C}$ content, on soil microbial biomass (Table 1), once that the microbial biomass growth and function are related to substrate $\mathrm{C}$ input into systems and amending the soil with crop residues always induces an increase in soil microbial biomass.

For example, in a long-term field experiment established in the USA, TU et al. (2006) evaluated the effect of transitional practices from conventional to organic farming on the size of the soil microbial communities. The results showed that the microbial biomass $\mathrm{C}(\mathrm{MBC})$ was highest in the organic plots compared to conventional plots. According to the 
Table 1 - Microbial biomass C (MBC) content related with C inputs in the soil.

\begin{tabular}{lccc}
\hline Agricultural System & MBC $\left(\mathrm{mg} \mathrm{kg}^{-1}\right)$ & $\mathrm{C}$ input $\left(\mathrm{kg} \mathrm{ha}^{-1}\right)$ & Reference \\
\hline Organic & 90 & 2,000 & KAPKIYAI et al., 1999. \\
Conventional & 54 & - & XAVIER et al., 2006 \\
Organic & 126 & 5,500 & ARAÚJO et al., 2008 \\
Conventional & 92 & - & MELERO et al., 2006 \\
Organic & 142 & 8,100 & TU et al., 2006 \\
Conventional & 64 & - & \\
Organic & 410 & - & 10,000 \\
Conventional & 200 & - & \\
Organic & 350 & & \\
Conventional & 220 &
\end{tabular}

authors, the significant differences in microbial biomass $\mathrm{C}$ between the organic and conventional farming likely reflect the accumulative impact of organic $\mathrm{C}$ inputs during 2000 and 2002, in organic farming, on the size of microbial biomass. Previously, FLIEßBACH \& MADER (2000), in a long term experiment (18 years in organic farming) with permanent organic inputs, observed a higher microbial biomass (45-64\% higher in organic farming systems than the respective conventional farming).

A field study was carried out, in Spain, by MELERO et al. (2006) evaluated the microbial biomass in soil under organic and conventional farming. The results showed that the microbial biomass was significantly higher under organic than conventional management, in all sampling periods, due to greater supply of available $\mathrm{C}$. The affirmation that the organic input increases the soil microbial biomass was confirmed recently by ARAÚJO et al. (2008) which evaluated the soil organic $\mathrm{C}$ and microbial biomass in different plots planted with "acerola" orchard (Malphigia glaba) under six, twelve, eighteen and twenty-four months of soil organic management, in Brazil. From the twelve month of organic management, the highest microbial biomass $\mathrm{C}$ values were found and significant differences between conventional and organic management were observed, while the highest organic $\mathrm{C}$ values were observed after twenty-four months. These authors attributed the increase in soil microbial biomass to long-term $\mathrm{C}$ inputs in organic farming systems.

In organic farming, crop rotations with legumes and organic fertilization have a positive influence on soil microbial biomass through greater return in crop residues (GAJDA \& MARTYNIUK, 2005; STARK, 2008). Microbial and biochemical analyses of soil under winter wheat in a field trial with various cultivation systems (organic, conventional and monoculture) were performed during 3 growing seasons by GADJA\& MARTYNIUK (2005). The organic system consisted of 5 fields on which the following crops are rotated: potato - spring barley + intercrop - grass/clover mixture (1st year) - grass/clover mixture (2nd year) winter wheat. In the conventional-short rotation system with 3 fields winter rape, winter wheat and spring barley are grown in a conventional-monoculture. The soil microbial biomass $\mathrm{C}$ and $\mathrm{N}$ contents in the conventional farming were generally significantly lower than those in the soil from the organic farming, indicating that substantial disturbances may occur in the microbial biomass of the conventional agriculture.

Afterward, STARK (2008) evaluated the effect of two organic and conventionally managed sites on soil microbial biomass. The organic site has been managed under a low-input 6-year rotation (Lolium perenne, Medicago sativa and Trifolium repens) and organic fertilization with compost or manure. The results showed positive effect of this management on soil microbial biomass.

The influence of different farming systems on microbial community structure were analyzed using soil samples from long-term field experiment in Switzerland by ESPERSCHÜTZ et al. (2007). This experiment comprised organic (organic fertilization) and conventional farming systems as well as an unfertilized control. They observed higher concentrations of phospholipids fatty acids (PFLAs) in organic farming, indicating a significant influence of this system on microbial biomass. Additionally, there was a strong response of soil microbial biomass to long-term organic fertilization.

The studies with organic farming shows that the quality of $\mathrm{C}$ inputs has a influence on soil microbial biomass content (CHOWDHURY et al., 2000; TU et al., 2006; XAVIER et al., 2006). Organic residues are composed by a mixture of carbohydrates, cellulose, 
lignin, proteins and other compounds. The variation in the carbon content of organic material is reflected in the constituency of the compound. Carbohydrates (for example, glucose) and proteins are abundant in plant biomass and excellent substrates for microbial growth and they disappear quickly during decomposition while cellulose and lignin disappear more slowly.

The addition of readily decomposable $\mathrm{C}$ sources such as glucose to the soil results in a rapid rise in microbial growth and activity. Thus, a high content of easily decomposable organic $\mathrm{C}$ can lead to fast growth of soil microbes, likely resulting in higher microbial biomass and activity. In this way, CHOWDHURY et al. (2000) observed that manure compost with high easily decomposable $\mathrm{C}$ was more effective than saw-dust and rice husk composts in enhancing soil microbial biomass $\mathrm{C}$.

The soil microbial biomass behavior is also governed by ratio of carbon and nitrogen $(\mathrm{C} / \mathrm{N}$ ratio). Fresh residues are relatively rich in carbon compared with nitrogen ( $\mathrm{C} / \mathrm{N}>20)$. Thus, during decomposition, soil microbial utilize reduced carbon as a respiratory substrate while accumulating carbon in the walls of their bodies (microbial biomass), these process is known as imobilization. In this process, $\mathrm{N}$ from organic residues, ammonium and nitrate ions from soil are also immobilized to microbial biomass. Imobilization is particularly evident during residues decomposition with high $\mathrm{C} / \mathrm{N}$ ratio, favoring increase in microbial biomass, conform reported by TU et al. (2006), which examined how different regimes of organic management impact microbial biomass and activities, and determined how the resulting changes in microbial activities influence nutrient $(\mathrm{N})$ availability for plants. The organic substrates used included composted cotton gin trash, animal manure and rye/vetch green manure. The results observed by authors showed that microbial biomass and microbial activity were generally higher in organic than in conventional managed soils, with cotton gin trash (higher $\mathrm{C} / \mathrm{N}$ ratio) as the most effective. Straw mulching further enhanced microbial biomass, activity, and potential $\mathrm{N}$ availability by 42,64 , and $30 \%$, respectively, relative to non-mulched soils, likely per improving $\mathrm{C}$ and water availability for soil microbes.

The results showed previously related the behavior of soil microbial biomass in soil of temperate regions. The studies conducted in tropical soils under organic farming show, generally, lower soil microbial biomass content, once that there are high soil microbial activity and the decomposition, influenced soil temperature. However, the results show positive effect of organic farming on soil microbial biomass, especially in soil with high content of sand and low fertility
(XAVIER et al., 2006; ARAÚJO et al., 2008; SAMPAIO et al., 2008). This is extremely important for tropical soils, once the microbial biomass soil is a pool of nutrients available for plant uptake (TU et al., 2003; WANG et al., 2004).

The effect of practices in organic farming on soil microbial biomass in sand soil was studied by XAVIER et al. (2006), SAMPAIO et al. (2008) and ARAÚJO et al. (2008, 2009), which observed increase in microbial biomass in soil under organic farming when compared with conventional farming. In these studies, the increase in microbial biomass was due the permanent input of organic residues with high $\mathrm{C} / \mathrm{N}$ ratio, as "carnauba" straw (XAVIER et al., 2006; ARAÚJO et al., 2008), applied, in localized form, under plant canopies (XAVIER et al., 2006; SAMPAIO et al., 2008). The permanent input of organic residues also favored the increase of microbial biomass in depth (XAVIER et al., 2006).

\section{CONCLUSION}

The different agricultural practices can cause positive or negative effects on soil microbial and organic matter content. In the case of organic farming, several studies has showed that the agricultural practices in this agricultural system, such as addition of compost, straw and natural amendments, promotes positive changes in the soil microbiological and biochemical process, resulting in the increase of soil microbial biomass. In this way, the organic systems are extremely important for the increase of soil fertility and the maintenance of the environmental sustainability.

\section{ACKNOWLEDGEMENTS}

The authors are grateful to "Conselho Nacional de Desenvolvimento Cientifico e Tecnológico" (CNPq) for financial support of the research of 'Soil Microbial Ecology in Mid-North Region' group (UFPI-CNPq) and for their fellowships (Research's Productivity).

\section{REFERENCES}

ARAÚJO, A.S.F. et al. Effect of glyphosate on the microbial activity of two Brazilian soils. Chemosphere, v.52, p.799804, 2003. Available from: <http://dx.doi.org/10.1016/S00456535(03)00266-2>. Accessed: Feb. 15, 2010. doi:10.1016/ S0045-6535(03)00266-2.

ARAÚJO, A.S.F. et al. Responses of soil microbial biomass and activity for practices of organic and conventional farming systems in Piauí state, Brazil. European Journal of Soil Biology, v.44, p.225-230, 2008. Available from: <http:// dx.doi.org/10.1016/j.ejsobi.2007.06.001>. Accessed: Feb. 15, 2010. doi:10.1016/j.ejsobi.2007.06.001. 
ARAÚJO, A.S.F. et al. Soil microbial activity in conventional and organic agricultural systems. Sustainability, v.1, p.268$276,2009$.

ARAÚJO, A.S.F.; MONTEIRO, R.T.R. Microbial biomass and activity in a Brazilian soil amended with untreated and composted textile sludge. Chemosphere, v.64, p.1028-1032, 2006. Available from: <http://dx.doi.org/10.1016/j.chemosphere.2006.01.040>. Accessed: Feb. 15, 2010. doi:10.1016/j.chemosphere.2006.01.040.

AYAGA, G. et al. Enhanced biological cycling of phosphorus increases its availability to crops in low-input sub-Saharan farming systems. Soil Biology \& Biochemistry, v.38, p.8190, 2006. Available from: <http://dx.doi.org/10.1016/ j.soilbio.2005.04.019>. Accessed: Set. 20, 2009. doi: 10.1016/ j.soilbio.2005.04.019.

BETTIOL, W. et al. Soil organisms in organic and conventional cropping systems. Scientia Agricola, v.59, p.656-572, 2002. Available from: <http://dx.doi.org/10.1590/ S0103-90162002000300023>. Accessed: Feb. 20, 2010. doi: $10.1590 / \mathrm{S} 0103-90162002000300023$.

BLOEM, J.; BREURE, A.M. Microbial indicators. In: BREURE, A.M. et al. (Ed). Bioindicators/biomonitors. Principles, assesment, concept. Amsterdam: Elsevier, 2002. p.43-61.

BRIAR, S.S. et al. Soil nematode community, organic matter, microbial biomass and nitrogen dynamics in field plots transitioning from conventional to organic management. Applied Soil Ecology, v.37, p.256-266, 2007. Available from: <http://dx.doi.org/ 10.1016/j.apsoil.2007.08.004>. Accessed: Feb. 20, 2010. doi:10.1016/j.apsoil.2007.08.004.

BROOKES, P.C. The soil microbial biomass: concept, measurement and applications in soil ecosystem research. Microbes and Environment, v.16, p.131-140, 2001.

CARTER, M.R. et al. Interpretation of microbial biomass for soil quality assessment in humid temperate regions. Canadian Journal of Soil Science, v.79, p.507-520, 1999.

CHOWDHURY, M.A.H. et al. Microbial biomass, S mineralization and $\mathrm{S}$ uptake by African millet from soil amended with various composts. Soil Biology \& Biochemistry, v.32, p.845-852, 2000. Available from: <http://dx.doi.org/10.1016/ S0038-0717(99)00214-X>. Accessed: Feb. 20, 2010. doi:10.1016/S0038-0717(99)00214-X.

DICK, R.P. Soil enzymes activities as integrative indicator of soil health. In: PANKHURST, C. et al. (Eds). Biological indicators of soil Health. Cambridge: $\mathrm{CAB}$ International, 1997. p.121-156.

DORAN, J.W.; PARKIN, T.B. Defining and assessing soil quality. In: DORAN, J.W. et al. (Eds.). Defining soil quality for a sustainable environment. Madison, SSSA, 1994. p.321 .

ESPERSCHÜTZ, J. et al. Response of soil microbial biomass and community structures to conventional and organic farming systems under identical crop rotations. FEMS Microbiology Ecology, v.61, p.26-37, 2007.

FLIEßBACH, A.; MADER, P. Microbial biomass and sizedensity fractions differ between soils of organic and conventional agricultural systems. Soil Biology and Biochemistry, v.32, p.757-768, 2000. Available from: $<$ http://dx.doi.org/10.1016/ S0038-0717(99)00197-2>. Accessed: Dec. 20, 2009. doi:10.1016/S0038-0717(99)00197-2.

GAJDA, A.; MARTYNIUK, A. Microbial biomass $\mathrm{C}$ and $\mathrm{N}$ and activity of enzymes in soil under winter wheat grown in different crop management systems. Polish Journal of Environmental Studies, v.14, p.159-163, 2005.

GLOVER, J.D. et al. Systematic method for rating soil quality of conventional, organic, and integrated apple orchards in Washington State. Agriculture, Ecosystems \& Environment, v.80, p.29-45, 2000. Available from: <http://dx.doi.org/ 10.1016/S0167-8809(00)00131-6>. Accessed: Dec. 20, 2009. doi:10.1016/S0167-8809(00)00131-6.

GREENE, C.; KREMEN, A. U.S. Organic Farming in 20002001: adoption of Certified systems. Washington, DC.: Resource Economics Division, Economic Research Service, USDA, 2003. 55p. (Agriculture Information Bulletin n.780).

GREGORICH, E.G. Towards a minimum data set to assess soil organic-matter quality in agricultural soils. Canadian Journal of Soil Science, v.74, p.367-385, 1994.

GUANAPALA, N.; SCOW, K.M. Dynamics of soil microbial biomass and activity in conventional and organic farming systems. Soil Biology \& Biochemistry, v.30, p.805-816, 1998.

HANEY, R.L. et al. Soil carbon and nitrogen mineralization as affected by atrazine and glyphosate. Biology and Fertility of Soils, v. 35, p. $35-40,2002$. Available from: $<\mathrm{http}: / /$ dx.doi.org/10.1007/s00374-001-0437-1>. Accessed: dec 20, 2009. doi: 10.1007/s00374-001-0437-1.

HORRIGAN, L. et al. How sustainable agriculture can address the environmental and human health harms of industrial agriculture? Environmental Health Perspectives, v.110, p.445-456, 2002.

JENKINSON, D.S.; LADD, J.N. Microbial biomass in soil: measurement and turnover. In: PAUL, E.A.; LADD, J.N. (Ed). Soil biochemisty. New York: Marcel Dekker, 1981. p.415471.

KAISER, E.A. et al. Evaluation of methods to estimates the soil microbial biomass and the relationship with soil texture and organic matter. Soil Biology \& Biochemistry, v.24, p.675-683, 1992 .

KAPKIYAI, J.J. et al. Soil organic matter and nutrient dynamics in a Kenyan nitisol under long-term fertilizer and organic input. Soil Biology \& Biochemistry, v.31, p.1773-1782, 1999. Available from: <http://dx.doi.org/10.1016/S00380717(99)00088-7>. Accessed: Dec. 20, 2009. doi:10.1016/ S0038-0717(99)00088-7.

LAGOMARSINO, A. et al. Soil biochemical indicators as a tool to assess the short-term impact of agricultural management on changes in organic $\mathrm{C}$ in a Mediterranean environment. Ecological Indicators, v.9, p.518-527, 2009. Available from: $<$ http://dx.doi.org/ 10.1016/j.ecolind.2008.07.003>. Accessed: Dec. 20, 2009. doi:10.1016/j.ecolind.2008.07.003. 
LIMA, H.V. et al. Indicadores de qualidade do solo em sistemas de cultivo orgânico e convencional no semi-árido cearense. Revista Brasileira de Ciência do Solo, v.31, p.1085-1098, 2007. Available from: $<\mathrm{http}: / / \mathrm{dx}$.doi.org/10.1590/S010006832007000500024>. Accessed: Dec. 20, 2009. doi: 10.1590/ S0100-06832007000500024.

LOTTER, D. organic agriculture. Journal of Sustainable Agriculture, v.21, p.1-4, 2003.

LUNDQUIST, E.J. et al. Rapid response of soil microbial communities from conventional, low input, and organic farming system to a wet/dry cycle. Soil Biology and Biochemistry, v.31, p.1661-1675, 1999.

LUPWAYI, Z. et al. Soil microbial biomass and diversity respond to tillage and sulphur fertilizers. Canadian Journal of Soil Science, v.81, p.577-589, 2001.

MALUCHE-BARETTA, C.R.D. et al. Atributos microbianos e químicos do solo em sistemas de produção convencional e orgânico de maçãs no estado de Santa Catarina. Revista Brasileira de Ciência do Solo, v.31, p.655-665, 2007. Available from: <http://dx.doi.org/10.1590/S010006832007000400006>. Accessed: Dec. 20, 2009. doi: 10.1590/ S0100-06832007000400006.

MELERO, S. et al. Chemical and biochemical properties in a silty loam soil under conventional and organic management. Soil Tillage Research, v.90, p.162-170, 2006. Available from: $<$ http://dx.doi.org/10.1016/j.still.2005.08.016>. Accessed: Dec. 20, 2009. doi:10.1016/j.still.2005.08.016.

MELO, W.J. Manejo: aspectos biológicos. In: PEREIRA, V.P. $(E d)$. Solos altamente susceptíveis à erosão: manejo visando à recuperação dos solos altamente susceptíveis à erosão. Jaboticabal, FCAV/UNESP/SBCS, 1994. p.123148.

MONOKROUSOS, N. et al. The response of soil biochemical variables to organic and conventional cultivation of Asparagus sp. Soil Biology \& Biochemistry, v.40, p.198-206, 2008. Available from: <http://dx.doi.org/10.1016/j.soilbio.2007.08.001>. Accessed: Dec. 20, 2009. doi:10.1016/j.soilbio.2007.08.001

OEHL, F. et al. Impact of long-term conventional and organic farming on the diversity of arbuscular mycorrhizal fungi. Oecologia, v.138, p.574-583, 2004.

OLIVEIRA, F.R.A. et al. Indicadores de qualidade do solo em área de mata e cultivado com cana orgânica e convencional. Revista Brasileira de Agroecologia, v.2, p.1299-1302, 2007.

PARFITT, R.L. et al. Relantioships between soil biota, nitrogen and phosphorus availability, and pasture growth under organic and conventional management. Applied Soil Ecology, v.28, p.1-13, 2005. Available from: <http://dx.doi.org/10.1016/ j.apsoil.2004.07.001>. Accessed: Dec. 20, 2009. doi:10.1016/ j.apsoil.2004.07.001.

POWLSON, D.S. et al. Measurement of soil microbial biomass provides an early indication of changes in total organic matter due to straw incorporation. Soil Biology \& Biochemistry, v.19, p.159-164, 1987.
REGANOLD, J.P. et al. Long-term effects of organic and conventional farming on soil erosion. Nature, v.330, p.370$372,1987$.

RIGBY, D.; CACERES, D. Organic farming and the sustainability of agricultural systems. Agricultural Systems, v.68, p.21-40, 2001.

SÁ, J.C.M. Manejo da fertilidade do solo no sistema plantio direto. In: SIQUEIRA, J.O. (Ed.). Interrelação fertilidade, biologia do solo e nutrição de plantas. Lavras: SBCS, 1999. p.267-319.

SAMPAIO, D.B. et al. Avaliação de indicadores biológicos de qualidade do solo sob sistemas de cultivo convencional e orgânico de frutas. Ciência e Agrotecnologia, v.32, p.353-359, 2008.

STARK, C.H. Are soil biological properties and microbial community structure altered by organic farm management? In: IFOAM ORGANIC WORLD CONGRESS 16., 2008, Modena, Italy. Proceedings... Modena:IFOAM, 2008. p. 121-124.

THEODORO, V.C.A. et al. Carbono da biomassa microbiana e micorriza em solo sob mata nativa e agroecossistemas cafeeiros. Acta Scientiarum:Agronomy, v.25, p.147-153, 2003.

TOYOTA K. et al. Survival of bacterial and fungal populations following chloroform-fumigation: effects of soil matric potential and bulk density. Soil Biology \& Biochemistry, v.28, p.1545-1547, 1996.

TRUU, M. et al. Soil microbiological and biochemical properties for assessing the effect of agricultural management practices in Estonian cultivated soils. European Journal of Soil Biology, v.44, p.231-237, 2008. Available from: <http://dx.doi.org/ 10.1016/j.ejsobi.2007.12.003>. Accessed: Dec. 20, 2009. doi:10.1016/j.ejsobi.2007.12.003.

TU, C. et al. Root-parasitic nematodes enhance soil microbial activities and nitrogen mineralization. Microbial Ecology, v.46, p.134-144, 2003.

TU, C. et al. Soil microbial biomass and activity in organic tomato farming systems: effects of organic inputs and straw mulching. Soil Biology \& Biochemistry, v.38, p.247-255, 2006. Available from: <http://dx.doi.org/10.1016/ j.soilbio.2005.05.002>. Accessed: Dec. 20, 2009. doi:10.1016/ j.soilbio.2005.05.002.

WANG, W.J. et al. Predicting soil nitrogen mineralization dynamics with a modified double exponential model. Soil Science Society of America Journal, v.68, p.1256-1265, 2004.

WARDLE, D.A. A comparative assessment of factors which influence microbial biomass carbon and nitrogen levels in soil.

Biological Reviews of the Cambridge Philosophical Society, v.67, p.321-358, 1992. 
WATANABE, K.; HAMAMURA, N. Molecular and physiological approaches to understanding the ecology of pollutant degradation. Current Opinion in Biotechnology, v.14, p.289-295, 2003. Available from: <http://dx.doi.org/ 10.1016/S0958-1669(03)00059-4>. Accessed: Dec. 20, 2009. doi:10.1016/S0958-1669(03)00059-4.

WATSON, C.A. et al. Research to support the development of organic food and farming. In: KRISTIANSEN, P. et al. (Eds.). Organic agriculture: a global perspective. Collingwood: CSIRO, 2006. p.361-383.

WILLER, H.; YUSSEFI, M. The world of organic agriculture: statistics and emerging trends. Bonn: IFOAM, Germany, 2004. 167p.
XAVIER, F.A.S. et al. Biomassa microbiana e matéria orgânica leve em solos sob sistema agrícolas orgânico e convencional na Chapada da Ibiapaba - CE. Revista Brasileira de Ciência do Solo, v.30, p.247-258, 2006. Available from: <http:// dx.doi.org/10.1590/S0100-06832006000200006>. Accessed: Dec. 20, 2009. doi: 10.1590/S0100-06832006000200006.

ZELLES, L. Fatty acid patterns of phospholipids and lipopolysaccharides in the characterization of microbial communities in soil: a review. Biology and Fertility of Soils, v.29, p.111-129, 1999. Available from: <http://dx.doi.org/ 10.1007/s003740050533>. Accessed: Dec. 20, 2009. doi: $10.1007 / \mathrm{s} 003740050533$. 